\title{
Differential expression of immune response genes in Pacific oyster, Crassostrea gigas spat, fed with dinoflagellates Gymnodinium catenatum and Prorocentrum lima
}

\author{
Norma García-Lagunas ${ }^{1}$, Reyna Romero-Geraldo ${ }^{2}$ \\ Ana K. Kao-Godinez ${ }^{3}$ \& Norma Y. Hernández-Saavedra ${ }^{3}$ \\ ${ }^{1}$ Consejo Nacional de Ciencia y Tecnología (CONACyT), Departamento de Investigaciones Científicas \\ y Tecnológicas de la Universidad de Sonora (DICTUS), Hermosillo, Sonora, México \\ ${ }^{2}$ Tecnológico Nacional de México, Instituto Tecnológico de La Paz (ITLP) \\ La Paz, Baja California Sur, México \\ ${ }^{3}$ Centro de Investigaciones Biológicas del Noroeste (CIBNOR) \\ La Paz, Baja California Sur, México \\ Corresponding author: Norma Y. Hernández-Saavedra (nhernan04@ cibnor.mx)
}

\begin{abstract}
The effects of Gymnodynium catenatum and Prorocentrum lima, dinoflagellate species present in the Gulf of California, on marine bivalves, have demonstrated physiological alterations and changes in gene expression patterns; however, modification effects of the genes involved in immune defense are still poorly understood. This study analyzed the mRNA levels of five genes encoding for the immune defense of oyster Crassostrea gigas spat fed with a control diet (Isochrysis galbana alone) and a combination of the two toxic dinoflagellates. Expression levels of lipopolysaccharide (LPS)-binding protein 1,3-glucan and cavorting genes were higher in oysters exposed to the combined diets in all treatments compared to the non-toxic diet at day three, which was probably related with an activation of the oysters' immediate immune response during the first $24 \mathrm{~h}$. Protein 44 interferon-induced gene expression level was repressed in treatments with the highest dinoflagellate concentration and overexpressed in the diet with equal dinoflagellate concentration. Interaction protein-Toll and immunoglobulin gene transcript levels reached the highest values at day seven in oysters exposed to all combined diets. Then, the immune defense appeared to be activated in oyster spat as a response of toxins and/or extra-cellular compounds produced by the dinoflagellates.
\end{abstract}

Keywords: Crassostrea gigas; Prorocentrum lima; Gymnodinium catenatum; dinoflagellates; gene expression; immune response

Crassostrea gigas is one of the most cultured marine species in the world (Shumway, 1990). The Pacific oyster is cultured mainly in the northwestern region of Mexico. The occurrence of harmful algal blooms (HABs) have been identified previous to mortality episodes, but a clear correlation has not been established yet (Wikfors, 2005). During blooms, the bivalve can accumulate large amounts of marine toxins, causing behavioral and physiological symptoms (Galimany et al., 2008; Haberkorn et al., 2010); the accumulation of diarrheic and paralytic toxins produced by dinoflagellates Prorocentrum lima and Gymnodinium catenatum, respectively, has been reported for C. gigas
(Shumway, 1990). P. lima is a toxic benthic, epiphytic dinoflagellate, and known producer of diarrheic shellfish poisoning (DSP). Diarrheic shellfish toxins (DSTs) are lipophilic polyether compounds, including okadaic acid (OA), dinophysistoxin-1 (DTX1), DTX2 and other derivative forms (Blanco et al., 2007). G. catenatum is an athecate species, chain-forming dinoflagellate, and responsible for paralytic shellfish poisoning (PSP). Paralytic shellfish toxins (PSTs) are a group of neurotoxic alkaloids, grouped into three structural families: carbamate (saxitoxin-STX, neosaxitoxin-NEO and gonyautoxins-GTX1 to GTX4), decarbamoyl and N-sulfocarbamoyl (Oshima, 1995).

Corresponding editor: José Gallardo 
These dinoflagellate species have been associated with DSP and PSP episodes in different parts of the world, and in the Gulf of California, they have also been extensively used in aquatic toxicological studies (PintoSilva et al., 2005; Wikfors, 2005; Flórez-Barrós et al., 2011; García-Lagunas et al., 2013, 2015; RomeroGeraldo et al., 2014, 2016).

Molecular studies with both toxins cause differential expression level on the genes involved in immune (García-Lagunas et al., 2013; Mello et al., 2013; Lassundrie et al., 2014, 2015a,b). In other hand, proteins of immune system (as carvotin, Interaction protein-Toll, immunoglobulin and Protein 44 interferoninduced) on oyster spats had a detectable and differentiated concentration in response to the low $\left(3 \times 10^{2}\right.$ cell $\left.\mathrm{mL}^{-1}\right)$ and high concentrations $\left(3 \times 10^{3}\right.$ cell $\mathrm{mL}^{-1}$ ) of P. lima (M.A. Matus, pers. comm.). In this context, genes with functions in early immune response were selected, such as toll-interacting protein $(t l p)$, a ubiquitin-binding protein that interacts with TLR signaling components and is highly conserved in evolution from invertebrate to vertebrate (Zhang et al., 2015); cavortin (cvt), which is the major hemolymph protein of the Pacific oyster, characterized as the hemocyte $\mathrm{Cu} / \mathrm{Zn}$ superoxide dismutase (Lambert et al., 2007; Scotti et al., 2007); lipopolysaccharide and $\beta-1,3$ glucan-binding protein (lgbp), which is a pattern recognition protein (PRP) that recognizes lipopolysaccharide and $\beta-1,3$-glucan $(\beta G)$ and subsequently triggers innate immunity (Romero-Geraldo et al., 2014). Additionally, interferon-induced protein 44 gene (if44) that may induce a cellular GTP depletion involved in cell cycle arrest (Renault et al., 2011) and immunoglobin domain (Ig) [and Leucine-rich repeat (LRR)] gene (imm) was selected because it is also a competent immune recognition module domain present in some proteins, which could function as immune effector or pro-inflammatory factor in oyster (Wang et al., 2017). Therefore, the aim of this study was to determine the effects of the simultaneous presence of two toxic dinoflagellates, $P$. lima and G. catenatum, on oyster C. gigas spat in combined diets. The specific objectives were to 1) assess their effects related to time and dinoflagellate cell density, 2) determine oysters' feeding preference in the combined diets, and 3) examine whether or not the combined diets induced differential expression of genes involved in oysters' immune response.

Gymnodinium catenatum was reared as described in García-Lagunas et al. (2013). P. lima and Isochrysis galbana were grown as described in Romero-Geraldo et al. (2014). Diploid individuals $(\mathrm{n}=180)$ of Pacific oyster spats (3-4 mm of length) were obtained from the hatchery and acclimated under controlled conditions of temperature, salinity, and oxygen for 10 days. The cell concentration of treatments was chosen by previous research by we work group (García-Lagunas et al., 2013, 2015; Romero-Geraldo et al., 2014). Oysters were exposed to four diets: (T1) combined diet of $G$. catenatum $\left(3 \times 10^{3}\right.$ cell $\left.\mathrm{mL}^{-1}\right)$ and $P$. lima $\left(3 \times 10^{2}\right.$ cell $\mathrm{mL}^{-1}$ ) and a fixed amount of Isochrysis galbana $\left(7.5 \times 10^{5}\right.$ cell $\left.\mathrm{mL}^{-1}\right)$; (T2) combined diet of $G$. catenatum $\left(1.5 \times 10^{3}\right.$ cell $\left.\mathrm{mL}^{-1}\right)$, P. lima $\left(1.5 \times 10^{3}\right.$ cell $\left.\mathrm{mL}^{-1}\right)$ and I. galbana $\left(7.5 \times 10^{5}\right.$ cell $\left.\mathrm{mL}^{-1}\right)$; (T3) combined diet of G. catenatum $\left(3 \times 10^{2}\right.$ cell $\left.\mathrm{mL}^{-1}\right)$ and P. lima $\left(3 \times 10^{3}\right.$ cell $\left.\mathrm{mL}^{-1}\right)$, I. galbana $\left(7.5 \times 10^{5}\right.$ cell $\left.\mathrm{mL}^{-1}\right)$; and (T4) a non-toxic control diet of I. galbana alone $\left(7.5 \times 10^{5}\right.$ cell $\left.\mathrm{mL}^{-1}\right)$. Groups of 50 oysters (in triplicate) were maintained in $100 \mathrm{~mL}$ transparent polypropylene containers with a 1:1 microalgal mixture in a final volume of $50 \mathrm{~mL}$. The microalgal ration was provided each day as a single dose; aeration was used during feeding experiments to avoid cell sedimentation. Five organisms of each experimental unit were randomly sampled after one, three, five and seven days. The samples were placed on Eppendorf ${ }^{\circledR}$ tubes, washed with sterile seawater and frozen at $-80^{\circ} \mathrm{C}$ until use. The number of filtered cells (FC) by the oysters was calculated using the Sedgwick-Rafter and hemocytometer counting chambers and optic microscope (Olympus BX41, Tokyo, Japan); the number of filtered cells was expressed as cell $\mathrm{mL}^{-1}$ (Fig. 1). Samples were thawed on ice, and total RNA was extracted with TRI Reagent $^{\circledR}$ (Life Technologies, Carlsbad, California). Samples $(n=5)$ were homogenized using a glass pestle. RNA quality and cDNA synthesis were verified and performed as described in García-Lagunas et al. (2013). Partial sequences of $C$. gigas were used to design a set of five primer pairs. The efficiency of each primer pair was determined using the standard curve method (Table 1). All qPCR reactions were conducted as described in García-Lagunas et al. (2013). The comparative CT method (Livak \& Schmittgen, 2001) was used to analyze gene expression levels. Data were analyzed using one-way ANOVA; significant differences were obtained with Fisher's multiple test comparison $(\alpha=$ $0.05)$. All analyses were performed with Statistic $8.0^{\circledR}$ software (StatSoft, Tulsa, Oklahoma).

The feeding behavior of C. gigas fed only with $I$. galbana diet maintained normal and completely consumed their food after three hours; the same behavior was observed during the experiment. However, the oysters did not wholly consume to I. galbana in T2 and $\mathrm{T} 3$ at $24 \mathrm{~h}$ (Fig. 1a), because the oysters fed the combined dinoflagellate diet showed a low feeding activity and production of pseudo-feces containing intact $P$. lima cells when the dinoflagellate was present. The oysters showed a preference for $G$. catenatum cells 


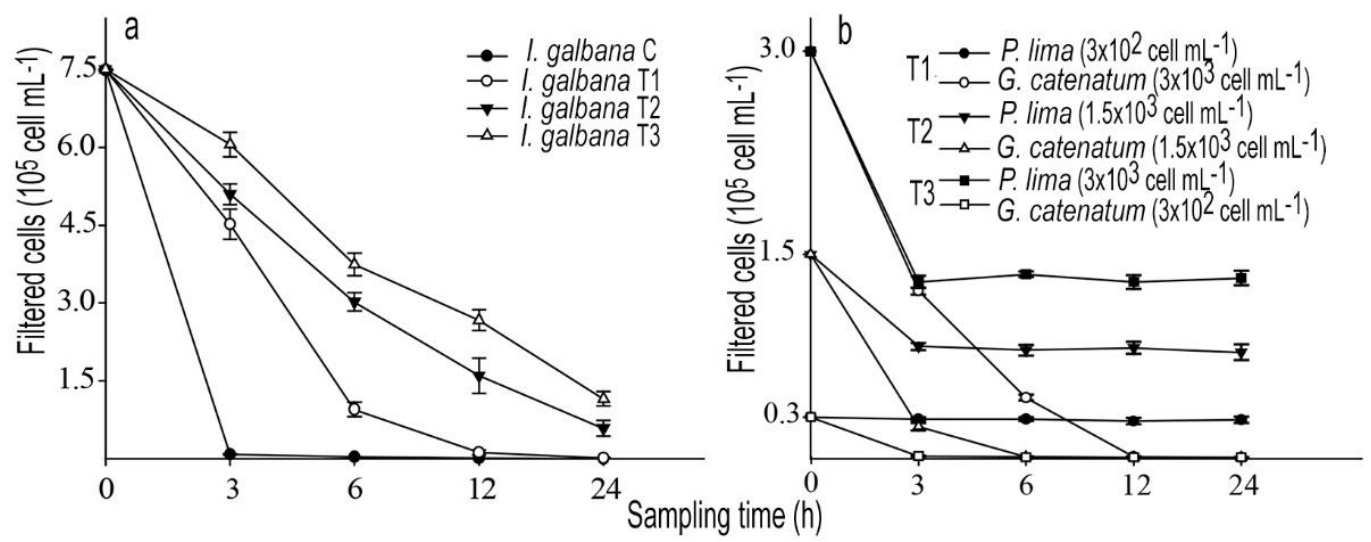

Figure 1. Consumption of control microalga and dinoflagellate cells by $C$. gigas in terms of filtered cells (FC) per mL in all treatments at $24 \mathrm{~h}$ of exposure; Bars represent mean $\pm \mathrm{SD}$.

Table 1. Primer sequences, expected amplicon size and efficiency corresponding to target (immune response) and reference genes* from Crassostrea gigas used for gene expression analysis after challenge with Prorocentrum lima and Gymnodinium catenatum. Fw: forward, Rv: reverse.

\begin{tabular}{|c|c|c|c|c|}
\hline Name & Sequence $5^{\prime}-3^{\prime}$ & Gene & $\begin{array}{c}\text { PCR } \\
\text { efficiency }\end{array}$ & $\begin{array}{c}\text { Access number } \\
\text { GenBank }\end{array}$ \\
\hline $\lg b p-\mathrm{FW}$ & TTGTCCAGTTCTCCCAGCTTCC & LPS binding protein and $\beta-$ & 1.95 & CB617438 \\
\hline $\lg p p-\mathrm{Rv}$ & GACACTGGAATGGGATGAAGAAC & 1,3 glucan & & \\
\hline$c v t-\mathrm{Fw}$ & АTCTCCATCTCCATGACGACG & Cavorting & 1.90 & AY256853 \\
\hline$c v t-\mathrm{Rv}$ & CGATGACAGCGGTATGAGAGG & & & \\
\hline if44-Fw & CATACTGGACGGCAACATACC & Interferon-induced protein 44 & 1.92 & FJ440108 \\
\hline if44-Rv & ATGAATCCTGTCCCCGAGAT & & & \\
\hline$t l p-\mathrm{FW}$ & GGCTTTCTCTATCCGTGGTA & Toll-interacting protein & 1.85 & ЕКC34473 \\
\hline$t l p-\mathrm{Rv}$ & GTTCTTGGCACCGTTGTAAG & & & \\
\hline imm-Fw & ATTTACAGCCGCTCCCATTCT & Inmunoglobulin & 1.89 & EU678312 \\
\hline imm-Rv & GCATCTCATTCGGTAAGGACTG & & & \\
\hline efl-Fw* & ACCATACAGTGAGGCTCGATTC & Elongation factor 1-alpha & 1.98 & AB122066 \\
\hline efl-Fw* & GTGGAAGCCTCAATCATGTTATC & & & \\
\hline gapdh-Fw* & GTTCAAATATGATTCAACTCACGG & Glyceraldehyde 3 phosphate & 2.0 & AJ544886 \\
\hline gapdh-Rv* & TGGATCCCGTTCGCAATATACG & dehydrogenase & & \\
\hline
\end{tabular}

in T1 treatment (Fig. 1b). The cellular concentration of G. catenatum decreased at $12 \mathrm{~h}$ while that of $P$. lima was stable until $24 \mathrm{~h}$ (T1). Similarly, when the concentration of $G$. catenatum and P. lima was equal (T2), C. gigas preferred to feed on G. catenatum and completely consumed it at six hours (Fig. 1b) while $P$. lima cell concentration was stable until $24 \mathrm{~h}$; the same behavior was observed during the experiment. Similar feeding behavior of $C$. gigas was observed in T3, in which the oysters preferred to feed on G. catenatum (Fig. 1b).

The expression level for if 44 gene in the diet with G. catenatum $>P$. lima $(\mathrm{T} 1)$ significantly $(P<0.05)$ down-regulated during the experiment on $C$. gigas. The diet with equal cell concentration of $G$. catenatum and $P$. lima caused a significant $(P<0.05)$ increase from day three (Fig. 2a). The $c v t$ gene expression level was constant until day three when it decreased significantly $(P<0.05)$ in all combined diets, below the control diet (Fig. 2b). For lgbp gene, the expression level upregulated until day three in all combined diets; after that, the expression level decreased significantly $(P<$ 0.05 ) except in T2. The treatment with G. catenatum < $P$. lima (T3) provoked mostly a decrease in the expression of lgbp (Fig. 2c).

Notably, the imm gene showed a down-regulation below the control diet on the first day, and increased significantly $(P<0.05)$ in expression level (twice more than the control level) in all combined diets at day seven (Fig. 2d). For the tlp gene the expression pattern was similar, with a notable decrease in expression level at day one of exposure to combined diets and an increase 


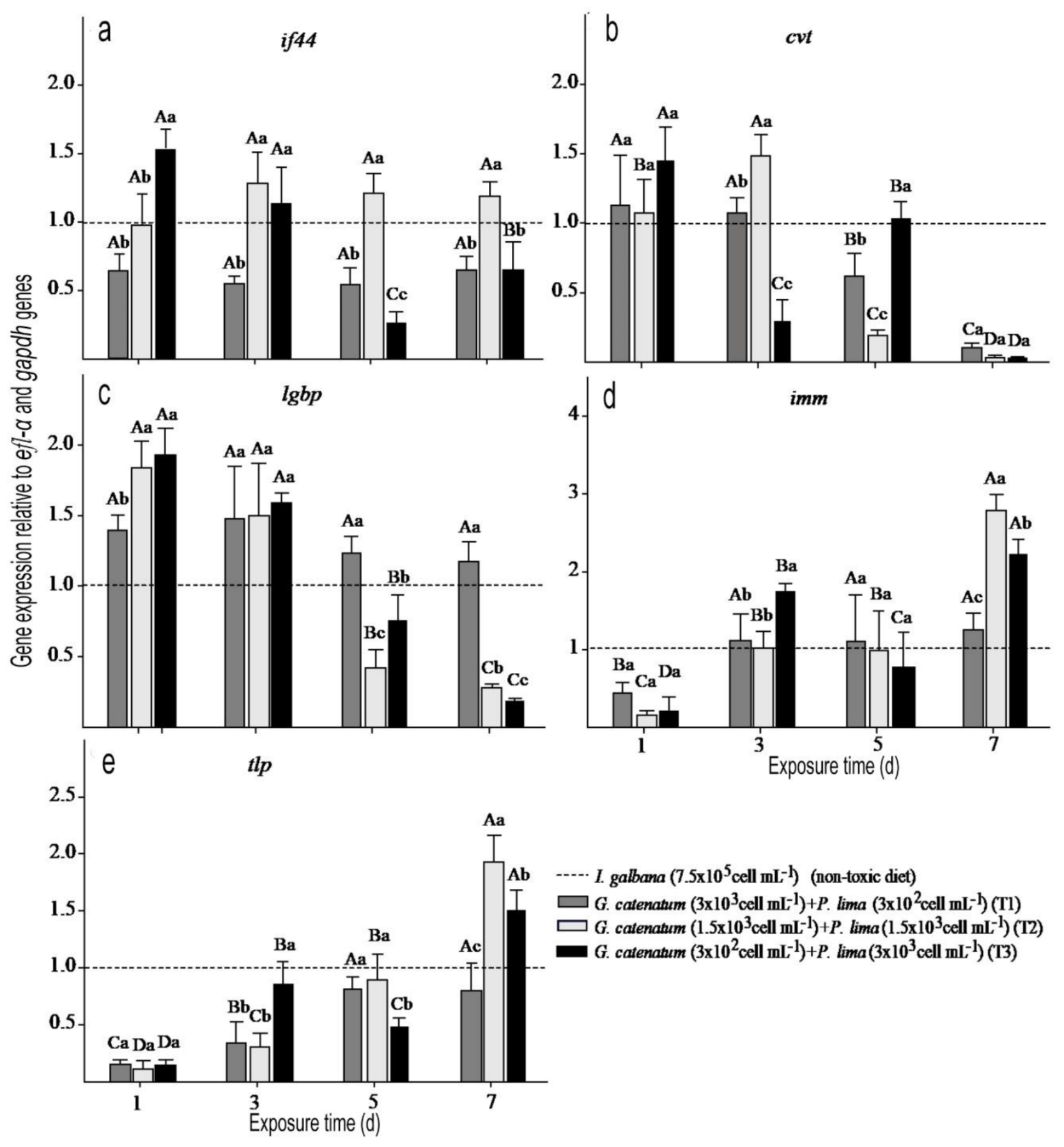

Figure 2. Expression level for if44, cvt, lgbp, imm, tlp genes respectively, in Crassostrea gigas spat fed with Isochrysis galbana $\left(7.5 \times 10^{5}\right.$ cell $\left.\mathrm{mL}^{-1}\right)$ non-toxic diet and mixed diets of Gymnodinium catenatum and Prorocentrum lima cells. G. catenatum $\left(3 \times 10^{3}\right.$ cell mL $\left.\mathrm{m}^{-1}\right)+P$. lima $\left(3 \times 10^{2}\right.$ cell mL $\left.{ }^{-1}\right)(\mathrm{T} 1) ;$ G. catenatum $\left(1.5 \times 10^{3}\right.$ cell mL $\left.^{-1}\right)+P$. lima $\left(1.5 \times 10^{3}\right.$ cell mL $\left.\mathrm{mL}^{-1}\right)$ (T2), and G. catenatum $\left(3 \times 10^{2}\right.$ cell $\left.\mathrm{mL}^{-1}\right)+P$. lima $\left(3 \times \times 10^{3}\right.$ cell $\left.\mathrm{mL}^{-1}\right)(\mathrm{T} 3)$. Bars represent mean $\pm \mathrm{SD}$. Values in column denoted by different lowercase letters indicate significant differences among the treatments, while different capital letters indicate significant differences among each exposure time (one-way ANOVA, Fisher's HSD test, $P<0.05$ ). The values with same letters show non-significant differences at $P<0.05$.

of expression level at day seven in combined $\mathrm{T} 2$ and $\mathrm{T} 3$ diets (Fig. 2e).

When $C$. gigas was fed on P. lima and G. catenatum (T1, T2 and T3 treatments) besides I. galbana, oysters changed food preferences. The feeding behavior expe- riments showed that $C$. gigas preferred to be fed on $G$. catenatum than $P$. lima. In the three treatments, the concentration of $P$. lima cells was stable from three hours to the end of the experiment (Fig. 1b) and also provoked the production of pseudo-feces containing 
Table 2. Summary of one-way ANOVA for gene expression levels involved in immune response from Crassostrea gigas with diets (treatments) and exposure time as factors.

\begin{tabular}{lcc}
\hline $\begin{array}{l}\text { Source of } \\
\text { variation }\end{array}$ & \multicolumn{2}{c}{$\begin{array}{c}\text { Treatment and } \\
\text { exposure time }\end{array}$} \\
\hline Gene & F-value & $P$-value \\
\hline if44 & 80.99 & $<0.0000$ \\
Cvt & 15.4 & 0.02 \\
Lgpb & 7.96 & 0.013 \\
Imm & 11.02 & 0.000 \\
Tlp & 4.17 & 0.033 \\
\hline
\end{tabular}

intact $P$. lima cells. The presence of dinoflagellate cells in feces is due to digestion activity decrease (Bauder $e t$ al., 2001), so the decrease of the digestion activity of $C$. gigas on P. lima could be related to the thecal valve and toxicity of this dinoflagellate species. Possibly, $C$. gigas was more affected by DSP toxins of $P$. lima related to PSP. Factors range from sensitivity, accumulation and elimination of the toxin by the bivalve, density of toxin-producing algae, exposure time and metabolic and structural consequences caused by the accumulation of toxins in bivalves (Bauder et al., 2001; Blanco et al., 2007).

The analysis of our results showed that the expression level in the studied genes was affected by cell concentration of the toxic dinoflagellates, as well as exposure time on $C$. gigas spat. These observations were consistent with those reported by other authors Romero-Geraldo \& Hernández-Saavedra, 2014; García-Lagunas et al., 2013, 2015; Romero-Geraldo et $a l ., 2014,2016)$. The expression level of $c v t$ and $l g b p$ gene showed a similar tendency, up-regulated for the three treatments at day three and down-regulated until the end of the experiment, indicating that DSP and PSP toxins inhibited the expression of these genes after five days of feeding. This observation was consistent with previous findings in the working group (GarcíaLagunas et al., 2013; Romero-Geraldo et al., 2014). Early activation of the immune response can be seen in the overexpression of these genes at first days. The lgbp gene plays a crucial role in the innate immunity of invertebrates (Girón-Perez, 2010), which suggests these genes could play a critical role in $C$. gigas- $G$. catenatum- $P$. lima interaction, allowing oysters to identify dinoflagellates as foreign or invasive elements. Carvotin gene in bivalves has been studied little. This study is the first report that has addressed the expression level of this gene about harmful algae.

For imm and tlp genes, the tendency of expression was similar in $\mathrm{T} 1$ and $\mathrm{T} 3$, although the expression level was higher in T3. On the contrary, in T2 (G. catenatum $=P$. lima $)$, these genes showed a different tendency with high expression at day seven. The presence of immune response could also be suggested by the overexpression of imm and tlp genes, as a result of a synergistic effect when both toxic dinoflagellates were present. Studies have suggested that bivalves, and principally bivalve cells of the immune system, can be adversely affected by HAB (Galimary et al., 2008; Lassudrie et al., 2015b). In some cases, a clear modulation of hemato-immunological parameters was observed, especially cellular immune response although most of these studies were performed under controlled laboratory conditions (Ferraz-Mello et al., 2010; Haberkorn et al., 2010; Mello et al., 2013; Lassudrie et al., 2015a). Little is known about the effect of harmful algae and their phycotoxins on responses in the immune system on oyster adults and less in oyster spats, due to the small size of spat, the study of immunity at the cellular level is challenging.

Then probably the co-occurrence of the two dinoflagellates could promote an increased susceptibility to infections in $C$. gigas spats. However, the possible molecular mechanism triggered by dinoflagellate toxins in mollusks is still not understood. Given that HAB may continue to intensify in the future (Hallegraeff, 2010), the co-occurrence of HAB and their toxins may become more common, so more research is imperative, mainly due to the unknown additive effects of multiple marine toxins on bivalve health.

Based on the results of this study, oyster $C$. gigas spats behaved differently in the presence of $P$. lima and G. catenatum. The simultaneous presence in combined diets of two dinoflagellates generated change in feed behavior of oysters with higher preference for feeding G. catenatum. The consumption of toxic dinoflagellates by oyster caused changes at the expression level of the genes involved in the immune response. The expression level was affected by cell concentration of the dinoflagellates, as well as exposure time when the immune response in oyster spats was probably activated for the defense of PST or DST toxins and/or extra-cellular compounds produced by dinoflagellates.

\section{ACKNOWLEDGMENTS}

The authors are grateful to CONACYT (National Council for Science and Technology in Mexico) for scholarship (278236) and funding project CONACYT CB07 083442; to C. Aldana and A. Green from the Live Food Lab of the Aquaculture Program for providing live food for the experiments; to M.A. Murillo Gallo and D. Fischer for English edition. 


\section{REFERENCES}

Bauder, A.G., Cembella, A.D., Bricelj, V.M. \& Quilliam, M.A. 2001. Uptake and fate of diarrhetic shellfish poisoning toxins from the dinoflagellate Prorocentrum lima in the bay scallop Argopecten irradians. Marine Ecology Progress Series, 213: 39-52.

Blanco, J., Mariño, C., Martín, H. \& Acosta, C.P. 2007. Anatomical distribution of diarrhetic shellfish poisoning (DSP) toxins in the mussel Mytilus galloprovincialis. Toxicon, 50(8): 1011-1018.

Ferraz-Mello, D., de Oliveira, L.A. \& Barracco, M.A. 2010. Comparative study of various immune parameters in three bivalve species during a natural bloom of Dinophysis acuminata in Santa Catarina Island, Brazil. Toxins, 2: 1166-1178. doi: 10.3390/ toxins2051166

Flórez-Barrós, F., Prado-Alvarez, M., Méndez, J. \& Fernández-Tajes, J. 2011. Evaluation of genotoxicity in gills and hemolymph of clam Ruditapes decussatus fed with the toxic dinoflagellate Prorocentrum lima. Journal of Toxicology and Environmental Health, Part A, 74(15-16): 971-979.

Girón-Pérez, M.I. 2010. Relationships between innate immunity in bivalve molluscs and environmental pollution. CONACYT.

Galimany, E., Sunila, I., Hégaret, H., Ramón, M. \& Wikfors, G.H. 2008. Pathology and immune response of the blue mussel (Mytilus edulis L.) after an exposure to the harmful dinoflagellate Prorocentrum minimum. Harmful Algae, 7(5): 630-638.

García-Lagunas, N., Romero-Geraldo, R. \& HernándezSaavedra, N.Y. 2013. Genomics study of the exposure effect of Gymnodinium catenatum, a paralyzing toxin producer, on Crassostrea gigas defense system and detoxification genes. Plos One, 8(9): 72323.

García-Lagunas, N., Romero-Geraldo, R. \& HernándezSaavedra, N.Y. 2015. Changes in gene expression and histological injuries as a result of exposure of Crassostrea gigas to the toxic dinoflagellate Gymnodinium catenatum. Journal of Molluscan Studies, 82(1): 193200.

Haberkorn, H., Lambert, C., Le Goïc, N., Guéguen, M., Moal, J., Palacios, E. \& Soudant, P. 2010. Effects of Alexandrium minutum exposure upon physiological and hematological variables of diploid and triploid oysters, Crassostrea gigas. Aquatic Toxicology, 97(2): 96-108.

Hallegraeff, G.M. 2010. Ocean climate change, phytoplankton community responses, and harmful algal blooms: a formidable predictive challenge. Journal of Phycology, 46(2): 220-235.
Lambert, C., Soudant, P., Dégremont, L., Delaporte, M., Moal, J., Boudry, P. \& Samain, J.F. 2007. Hemocyte characteristics in families of oysters, Crassostrea gigas, selected for differential survival during summer and reared in three sites. Aquaculture, 270(1-4): 276288.

Lassudrie, M., Soudant, P., Richard, G., Henry, N., Medhioub, W., Da Silva, P.M. \& De Montaudouin, X. 2014. Physiological responses of Manila clams Venerupis (= Ruditapes) philippinarum with varying parasite Perkinsus olseni burden to toxic algal Alexandrium ostenfeldii exposure. Aquatic Toxicology, 154: 27-38.

Lassudrie, M., Soudant, P., Nicolas, J.L., Fabioux, C., Lambert, C., Miner, P. \& Hégaret, H. 2015b. Interaction between toxic dinoflagellate Alexandrium catenella exposure and disease associated with herpesvirus OsHV-1 $\mu$ Var in Pacific oyster spat Crassostrea gigas. Harmful Algae, 45: 53-61.

Lassudrie, M., Wikfors, G.H., Sunila, I., Alix, J.H., Dixon, M.S., Combot, D., Soudant, P., Fabioux, C. \& Hégaret, H. 2015a. Physiological and pathological changes in the eastern oyster Crassostrea virginica infested with the trematode Bucephalus sp. and exposed to the toxic dinoflagellate Alexandrium fundyense. Journal of Invertebrate Pathology, 126: 51-63.

Livak, K.J. \& Schmittgen, T.D. 2001. Analysis of relative gene expression data using real-time quantitative PCR and the 2- $\Delta \Delta C T$ method. Methods, 25(4): 402-408.

Mello, D.F., da Silva, P.M., Barracco, M.A., Soudant, P. \& Hégaret, H. 2013. Effects of the dinoflagellate Alexandrium minutum and its toxin (saxitoxin) on the functional activity and gene expression of Crassostrea gigas hemocytes. Harmful Algae, 26: 45-51.

Oshima, Y. 1995. Postcolumn derivatization liquidchromatography method for paralytic shellfish toxins. Journal of AOAC International, 78: 528-532.

Pinto-Silva, C.C., Creppy, E.E. \& Matias, W.G. 2005. Micronucleus test in mussels Perna perna fed with the toxic dinoflagellate Prorocentrum lima. Archives of Toxicology, 79(7): 422-426.

Renault, T., Faury, N., Barbosa-Solomieu, V. \& Moreau, K. 2011. Suppression substractive hybridisation (SSH) and real time PCR reveal differential gene expression in the Pacific cupped oyster, Crassostrea gigas, challenged with Ostreid herpesvirus 1. Developmental \& Comparative Immunology, 35(7): 725-735.

Romero-Geraldo, R., García-Lagunas, N. \& HernándezSaavedra, N.Y. 2014. Effects of in vitro exposure to diarrheic toxin producer Prorocentrum lima on gene expressions related to cell cycle regulation and immune response in Crassostrea gigas. Plos One, 9(5): e97181. 
Romero-Giraldo, R. de J. \& Hernández-Saavedra, NY 2014. El estrés expresión génica en Crassostrea gigas (Thunberg, 1793) en respuesta a la exposición experimental a la dinoflagelado tóxico Prorocentrum lima (Ehrenberg) Dodge, 1975. Aquaculture Research, 45: 1512-1522.

Romero-Geraldo, R., García-Lagunas, N. \& HernándezSaavedra, N.Y. 2016. Crassostrea gigas exposure to the dinoflagellate Prorocentrum lima: histological and gene expression effects on the digestive gland. Marine Environmental Research, 120: 93-102.

Scotti, P.D., Dearing, S.C. \& Greenwood, D.R. 2007. Characterization of cavortin, the major haemolymph protein of the Pacific oyster (Crassostrea gigas). New Zealand Journal of Marine and Freshwater Research, 41: 91-101. doi: 10.1080/00288330709509898.

Received: 11 November 2018; Accepted: 7 March 2019
Shumway, S.E. 1990. A review of the effects of algal blooms on shellfish and aquaculture. Journal of the World Aquaculture Society, 21: 65-104.

Wang, X., Wang, M., Xu, Q., Xu, J., Lv, Z., Wang, L. \& Song, L. 2017. Two novel LRR and Ig domaincontaining proteins from oyster Crassostrea gigas function as pattern recognition receptors and induce expression of cytokines. Fish and Shellfish Immunology, 70: 308-318. doi: 10.1016/j.fsi.2017. 09.023.

Wikfors, G.H. 2005. A review and new analysis of trophic interactions between Prorocentrum minimum and clams, scallops, and oysters. Harmful Algae, 4(3): 585-592.

Zhang, R., Ruojiao, L., Jing, W., Shuyue, W., Mengran, Z., Xiaoli, H., Lingling, Z., Shi, W., Ruijia, W. \& Zhenmin, B. 2015. Identification, characterization, and expression profiling of the Tollip gene in Yesso scallop (Patinopecten yessoensis). Genes \& Genetic Systems, 90: 99-108. 